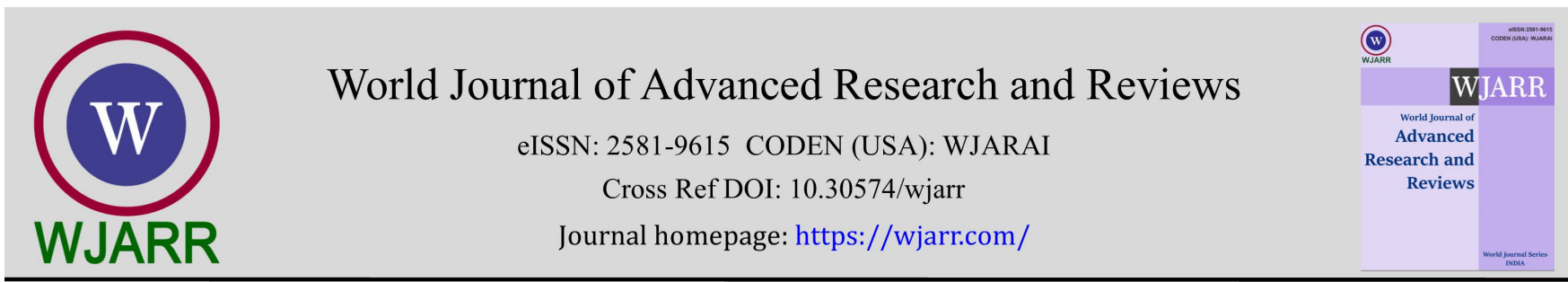

(RESEARCH ARTICLE)

Check for updates

\title{
Effect of eco-enzymes prepared from selected organic waste on domestic waste water treatment
}

\author{
Bharvi S. Patel $1{ }^{*}$, Bhanu R. Solanki ${ }^{2}$ and Archana U. Mankad ${ }^{3}$ \\ ${ }^{1}$ Post Graduate Student, Department of Botany, Bioinformatics and Climate Change Impacts Management, School of \\ Science, Gujarat University, Ahmedabad - 380009, Gujarat, India. \\ 2 Ph.D. Scholar, Department of Botany, Bioinformatics and Climate Change Impacts Management, School of Science, \\ Gujarat University, Ahmedabad - 380009, Gujarat, India. \\ ${ }^{3}$ Professor and Head, Department of Botany, Bioinformatics and Climate Change Impacts Management, School of Science, \\ Gujarat University, Ahmedabad - 380009, Gujarat, India.
}

World Journal of Advanced Research and Reviews, 2021, 10(01), 323-333

Publication history: Received on 12 March 2021; revised on 14 April 2021; accepted on 16 April 2021

Article DOI: https://doi.org/10.30574/wjarr.2021.10.1.0159

\begin{abstract}
Water Pollution has become a major problem with increasing urbanisation and rapid industrialisation. Despite the abundance of water, pollution causes the water to be less useful and more harmful to health, environment, and life on our planet. In past few years, many researchers have focussed on use of biological \& physical treatment methods that are cost-effective and cause no harm to the environment instead of chemical methods. The aim of the present work is to study the effect of organic solid wastes in the form of orange peels, marigold flowers, and neem leaves on domestic wastewater treatment. Eco-enzyme solutions were prepared using Dr. Rosukon's method from the wastes mentioned which involves mixing jaggery along with the wastes and water in the ratio of 1:3:10. The eco-enzyme solution was then allowed to be prepared through 90 days of fermentation process. The three eco-enzyme solutions - after 10 days of filtration - were then mixed with domestic wastewater samples individually keeping $90 \%$ wastewater and $10 \%$ ecoenzyme solution. The results after 50 days of digestion period suggests that orange eco-enzyme was the most effective in reducing Total Dissolved Solids (TDS) while Marigold eco-enzyme was most effective in reducing Chemical Oxygen Demand (COD).
\end{abstract}

Keywords: Eco-enzyme; Garbage enzyme; Bio-enzyme; Domestic Wastewater Treatment; Organic solid Waste Management

\section{Introduction}

Water is one of the most abundant, valuable, and important resources on the earth for the survival of all living forms as well as for day-to-day human activities [1]. But many people don't have access to safe clean water as a majority of the freshwater resources are polluted. Increasing world population has resulted in large amounts of waste being added to the water and that has resulted in almost 70-80\% of rivers and streams all across the world being polluted [2]. Wastewater is defined as water whose physical, chemical or biological properties have been changed as a result of the introduction of certain substances that render it unsafe for some purposes such as drinking. Amongst the types of wastewater, the three main types are Stormwater Runoff, Industrial Wastewater, and Domestic Wastewater. Domestic wastewater is generated from the residences and office buildings and can be classified into Greywater and Blackwater depending on the source [3]. Household practices like bathing, cleaning, cooking etc. lead to Greywater while that from excreting waste by urine, faeces, perspiration fall in Blackwater [4].

\footnotetext{
${ }^{*}$ Corresponding author: Bharvi S. Patel

Post Graduate Student, Department of Botany, Bioinformatics and Climate Change Impacts Management, School of Science, Gujarat University, Ahmedabad - 380009, Gujarat, India.
}

Copyright (C) 2021 Author(s) retain the copyright of this article. This article is published under the terms of the Creative Commons Attribution Liscense 4.0. 
The organic matter and other contaminants make the wastewater a breeding ground for a variety of pathogenic organisms like bacteria, viruses, fungi, and protozoa and cause a lot of water-related diseases [5]. Estimations suggest that around 1.1 billion people globally drink unsafe water. According to the World Bank, 21\% of India's communicable diseases are water related [6]. Wastewater treatment has become increasingly important as a result of the huge challenge it poses. The wastewater is a resource for 2 things, one water, and second the nutrients it contains [7]. Thus, it is very important to preserve the water quality for current and future generations and for the ecosystem to survive even when treating the wastewater [8].

In 2012, only around $20 \%$ of the wastewater produced globally was being treated, according to the fourth World Water Development Report. This highlights that currently there is technology available to treat water, but it is not being utilized and implemented at majority of the places due to affordability and feasibility [9]. Treatment of wastewater to remove the various pollutants in it can be accomplished using various methods which can be categorized into: Physical, Chemical, and Biological methods. Physiological and chemical treatment methods require advanced technologies, and trained technicians and thus higher energy and cost to be implemented. Biological treatment methods are very efficient energy \& cost wise and require simpler tools and thus in demand currently [10]. Enzymes can be utilized due to their catalytic potential for wastewater treatment as well. However, they have a limitation due to prohibitive cost involved with enzymes and thus not viable at very large scales [11].

On another hand, vegetable and fruit wastes are generated through various activities like producing, processing, eating, cooking, peeling, \& cutting. And a lot of this waste is dumped inadequately thus causing serious environmental and health concerns. Such dumped garbage is often stale, spoilt, and unfit for consumption. But the solid waste thus generated contains useful fibre content, moisture, and other nutrients [12]. Several examinations have found that up to $80 \%$ of such strong waste can be used again and thus reduce the pollution it causes [13]. One such way to utilise the fruit and vegetable waste is in creating eco-enzyme solutions from it. Eco-enzyme is a kind of vinegar prepared at home by fermentation of fresh kitchen waste like fruit and vegetable peels as substrate with sugar and water [14]. Dr. Rosukon Poompanvong invented the process of preparing the bio-enzyme by fermentation of sugar, water, and fruit and vegetable waste [15]. Bio-enzymes are multipurpose natural cleaners that can effectively replace harsh chemicals like bleach, phenyl, and other chemical solutions we typically use in our households. The various roles that eco-enzyme plays are anti-fungal, anti-bacterial, insecticidal and cleaning agent [16]. Bio-enzyme is a new and one of the trending methods used today to treat domestic wastewater, and neither much work has been done on bio-enzyme nor it is practised much in India. Its usage can help to minimise organic waste, reduce greenhouse emissions, and lessen burden on landfills [17].

\section{Material and methods}

The present study was carried out to determine the effect of 3 different types of eco enzyme solutions in domestic wastewater treatment.

\subsection{Materials}

The materials that have been used in the preparation of eco-enzyme solution are:

- Citrus peels (Orange) waste,

- Marigold flowers waste,

- Neem Leaves waste,

- Jaggery, \&

- Water

The apparatus that has been used for storing materials, testing \& measuring parameters are:

- Plastic air-tight bottles (for fermentation process during preparation of eco-enzyme),

- Dr Trust - Electronic Kitchen Scale (as weighing scale),

- Beaker (for taking out samples for parameters testing),

- HANNA pH meter (for measuring pH of wastewater and eco-enzyme solutions),

- HANNA TDS meter (for measuring TDS of wastewater and eco-enzyme solutions),

- Hach DR3900 spectrophotometer (for measuring COD of wastewater solution before and during the treatment with eco-enzyme solutions). 


\subsection{Collection and Preparation of Samples}

We collected citrus peels (orange), marigold flowers, and neem leaves waste from my house, neighbours, and surrounding area.

The water was collected from various sources of water pollution inside the home.

\subsubsection{Jaggery}

Jaggery is loaded with minerals \& antioxidants like selenium \& zinc. Among them, zinc helps in killing bacteria and it also has antibacterial properties [18].

\subsubsection{Citrus Fruit Peels}

Citrus fruit peels contain carbohydrates in the form of sugars, sucrose, glucose, fructose, etc. Organic acid is also present in citrus fruit peels, such as citric acid, malic acid, oxalic acid, succinic acid. The organic acids help to convert carbohydrates to alcohol [18].

\subsubsection{Marigold Flowers}

Marigold flower has shown anti-oxidant and anti-cancer properties in various studies due to it being a rich source of Xanthophylls called Lutein. Lutein is widely used in food, medicine, health care products and plays an important role in preventing and controlling diseases in the human body $[19,20]$.

\subsubsection{Neem Leaves}

Neem is a natural herb available in abundance in India. And it is found to be an effective disinfectant due to its antibacterial activity in killing pathogenic bacteria present in polluted water or wastewater to make the water safe for usage (especially in rural and tribal areas) [21]. Azadirachta indica (Neem) has shown strong potential in removing several harmful toxic metals and pathogenic microbes from wastewater along with improving quality parameters of water with minimal or no side effects [22].

\subsection{Experimental Design}

\subsubsection{Preparation of Eco-enzyme}

Ingredients for preparing

- Citrus eco-enzyme solution: Citrus peels waste + Jaggery + Distilled Water

- Marigold eco-enzyme solution: Marigold flowers waste + Jaggery + Distilled Water

- Neem leaves eco-enzyme solution: Neem leaves waste + Jaggery + Distilled Water

Composition: The composition ratio of ingredients for preparing Eco-enzyme is described below (table 1).

Table 1 Composition of ingredients for preparing Eco-enzyme.

\begin{tabular}{|c|c|c|c|}
\hline Sr. No. & Ingredients & Parts/Ratio & Weight/Volume \\
\hline 1. & Jaggery & 1 & $100 \mathrm{gm}$ \\
\hline \multirow{3}{*}{2.} & Citrus Peels Waste & \multirow{3}{*}{3} & \multirow{3}{*}{$300 \mathrm{gm}$} \\
\hline & Marigold Flowers Waste & & \\
\hline & Neem Leaves Waste & & \\
\hline 3. & Water & 10 & $1000 \mathrm{ml}(1 \mathrm{~L})$ \\
\hline
\end{tabular}

Procedure: The materials that have to be used for the preparation of eco-enzyme solutions are jaggery \& water along with fruit, flower, or leaves waste for respective solutions.

After the collection of waste, separation is done to ensure that no chemical substance enters into the system, which can affect the process. All the 3 types of wastes were then shredded into small pieces to increase the surface area for reaction. It is done so as to increase the rate of decomposition. 
We used Dr Trust - Electronic Kitchen Scale for measuring the weights of the ingredients.

The ratio used to prepare the eco-enzyme solution is 1:3:10. Thus one part of jaggery, three parts of respective wastes and ten-parts of water have to be mixed in an airtight plastic container for each of the three wastes separately (figure 1). The container must be in such a way that it can accommodate the eco-enzyme and still have 10-20\% space left empty [23].

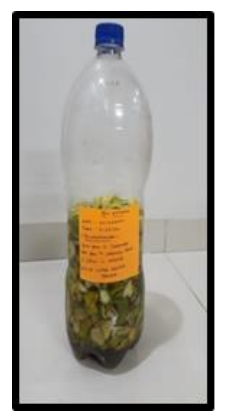

(a)

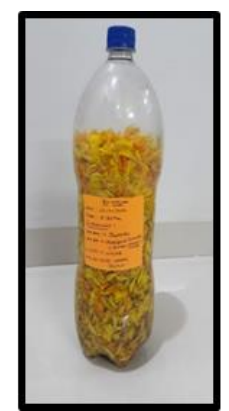

(b)

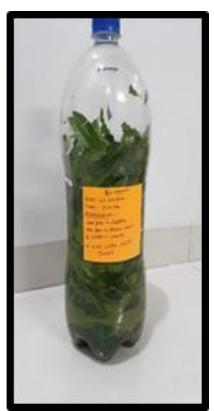

(c)

Figure 1 Eco-enzyme Production: (a) Orange eco-enzyme production, (b) Marigold eco-enzyme production, (c) Neem eco-enzyme production

The principle behind the enzyme preparation is the simple fermentation process. An airtight container is used to promote fermentation by minimizing oxygen. Usually, it takes three months for the eco-enzyme to be ready.

When the process of fermentation starts there will be some release of gases that will be built up in the space of the container. The bubble formation during the fermentation process is due to the release of gases. So, we must release the gases by opening the lid once in a day and the container must be closed again tightly. This must be repeated for one week and from the second week it can be opened in alternative days as the formation of gases will be reduced.

The enzyme prepared must be stored in a cool place at room temperature and should not be stored under direct sunlight. Settling of the citrus fruit peels in the bottom of the container and less bubble formation indicates the completion of the fermentation process.

After 90 days of fermentation, coloured liquids along with many small particles and some undigested residue was prepared in the container. The colour of orange, marigold, and neem eco-enzyme was light yellowish brown, brown, and dark greenish brown respectively. These coloured liquids were raw enzymes and it was needed to separate it out from other solid matter left after digestion. Filtration was done to obtain the prepared eco-enzyme to improve the structural and functional properties (figure 2).

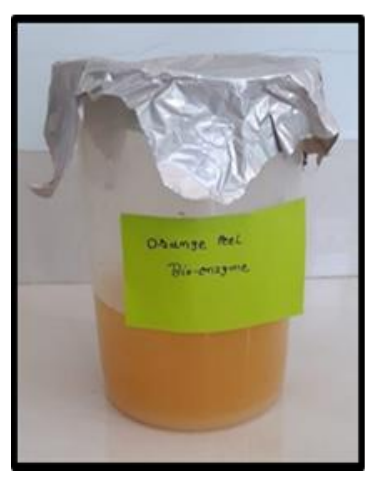

(a)

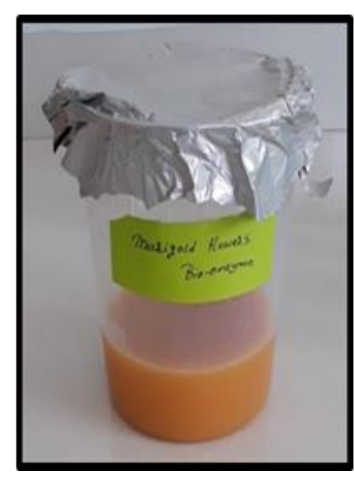

(b)

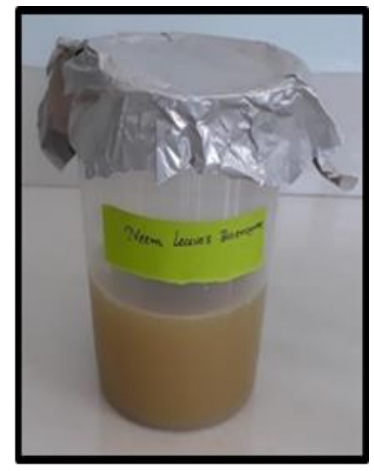

(c)

Figure 2 Eco-enzyme Solutions after Filtration: (a) Orange eco-enzyme solution, (b) Marigold eco-enzyme solution, (c) Neem eco-enzyme solution

Filtered bio-enzyme solution was kept separately in a closed container. The characterization of the bio-enzyme was done after 10 days of filtration [17]. 


\subsubsection{Preparation of Domestic Wastewater}

The domestic wastewater used in this study was prepared at home. The colour of the domestic wastewater was found to be grey.

Procedure

Collect the wastewater separately as prepared from various household activities that pollute water such as:

- Cleaning Utensils

- Laundry

- Washing fruits and vegetables

- Cooking

- Cleaning House

- Kitchen waste

- Body washing

- $\mathrm{NaCl}$

Mix the separately collected wastewater into a single large container to obtain the domestic wastewater (figure 3).

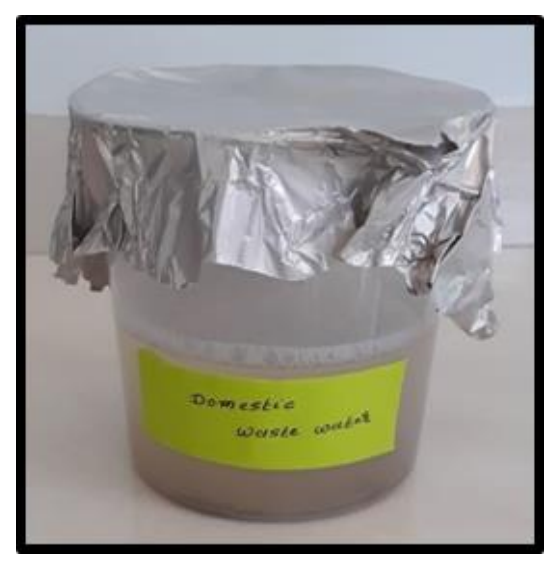

Figure 3 Domestic Wastewater Sample

Duration

The eco-enzyme was prepared at home and was kept to allow for fermentation for duration of 3 months. It was filtered at the end of the 90th day.

After 10 days of the filtration, the measurement of parameters was undertaken over a period of next 50 days.

\subsubsection{Domestic wastewater treatment using 3 different Eco-enzyme Solutions}

Procedure

- After 10 days of filtration of the three eco-enzyme solutions, their $\mathrm{pH}$ and TDS parameters were measured separately.

- Immediately after the domestic wastewater was prepared, its COD, $\mathrm{pH}$, and TDS reading were measured by taking out different samples.

- Three more domestic wastewater samples of $450 \mathrm{ml}$ each were taken out from the prepared domestic wastewater and were separately mixed with $50 \mathrm{ml}$ of each of the three eco-enzyme solutions giving us $10 \%$ eco-enzyme diluted wastewater samples (figure 4).

- $\quad \mathrm{pH}$, and TDS of the three samples hence prepared were measured at days $3,5,10,15,20,25,30,40$, and 50 after mixing.

- $\quad$ COD of three samples was measured on day 30 after mixing. 


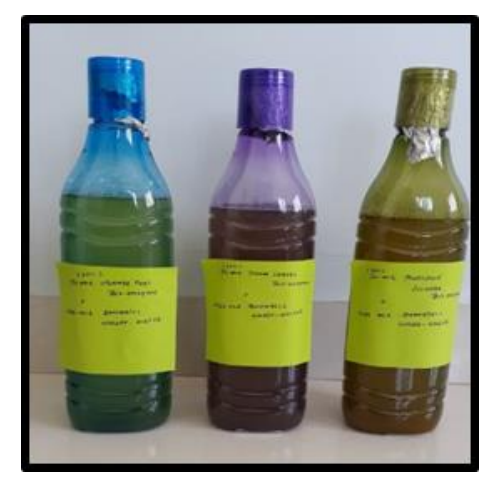

Figure 4 Samples with Domestic Wastewater \& Eco-enzyme: Left-most bottle has Orange eco-enzyme, Middle bottle has Marigold eco-enzyme and Rightmost bottle has Neem eco-enzyme added to Domestic wastewater

Parameter Tests Conducted

The tests that have been conducted are:

- $\quad \mathrm{pH}$ : The $\mathrm{pH}$ of the samples/solutions was measured using HANNA pH meter which immediately displays the $\mathrm{pH}$ reading (in the range of 1-14) of the solution on its digital display upon dipping the sensor part into the solution.

- $\quad$ TDS: The TDS of the samples/solutions was measured using HANNA TDS meter which immediately displays the TDS reading (display reading has to be multiplied by a factor of 100 to obtain actual TDS reading in $\mathrm{mg} / \mathrm{L}$ ) of the solution on its digital display upon dipping the sensor part into the solution.

- $\quad$ COD: The COD of the samples was measured for reading in mg/L using HACH DR3900 instrument in SICART Lab of Anand. It is a benchtop visible spectrum (320 - $1100 \mathrm{~nm})$, split beam spectrophotometer with over 220 pre-programmed methods optimized for laboratory water analysis. It provides optimised and accurate results for the parameters it is programmed for.

\section{Results}

\subsection{Characteristics of Eco-enzyme}

The characteristic of eco-enzyme solutions of orange peels, marigold flowers and neem leaves waste have been tabulated below (table 2).

Table 2 Characteristics of three different eco-enzyme (after 10 days of filtration).

\begin{tabular}{|l|l|l|l|}
\hline Parameters & $\begin{array}{l}\text { Orange peel waste } \\
\text { Eco-enzyme Value }\end{array}$ & $\begin{array}{l}\text { Marigold flowers } \\
\text { waste Eco-enzyme } \\
\text { Value }\end{array}$ & $\begin{array}{l}\text { Neem leaves waste } \\
\text { Eco-enzyme Value }\end{array}$ \\
\hline $\mathrm{pH}$ & 3.1 & 2.9 & 3.2 \\
\hline TDS $(\mathrm{mg} / \mathrm{L})$ & 1300 & 1400 & 2500 \\
\hline
\end{tabular}

The low pH value of eco-enzyme solutions prepared from orange peels, marigold flowers and neem leaves show its acidic nature. The TDS readings were quite high upon analysis.

\subsection{Characteristics of Domestic Wastewater}

Below table demonstrates the domestic wastewater characteristics used in the present study (table 3). 
Table 3 Domestic wastewater characteristics.

\begin{tabular}{|l|l|}
\hline Parameters & Domestic Wastewater Value \\
\hline $\mathrm{pH}$ & 7.1 \\
\hline TDS $(\mathrm{mg} / \mathrm{L})$ & 3800 \\
\hline COD $(\mathrm{mg} / \mathrm{L})$ & 1920 \\
\hline
\end{tabular}

The $\mathrm{pH}$ of domestic wastewater suggests it's slightly alkaline in nature. The TDS value is quite high.

\subsection{Characteristics of Domestic wastewater sample after treatment with Eco-enzyme}

The domestic wastewater sample was treated with $10 \%$ eco-enzyme solutions obtained from orange peels, marigold flowers, and neem leaves waste. The bottles were kept for digestion periods of 50 days, and the pH \& TDS were measured on $3,5,10,15,20,25,30,40$, and 50 days. While the parameter of COD was measured on the 30 th day. The results have been discussed below.

\subsection{1. $p H$}

After treatment with eco-enzyme the variation was observed in $\mathrm{pH}$ value of effluent and the corresponding variation in the characteristic of treated domestic wastewater samples is shown below (figure 5).

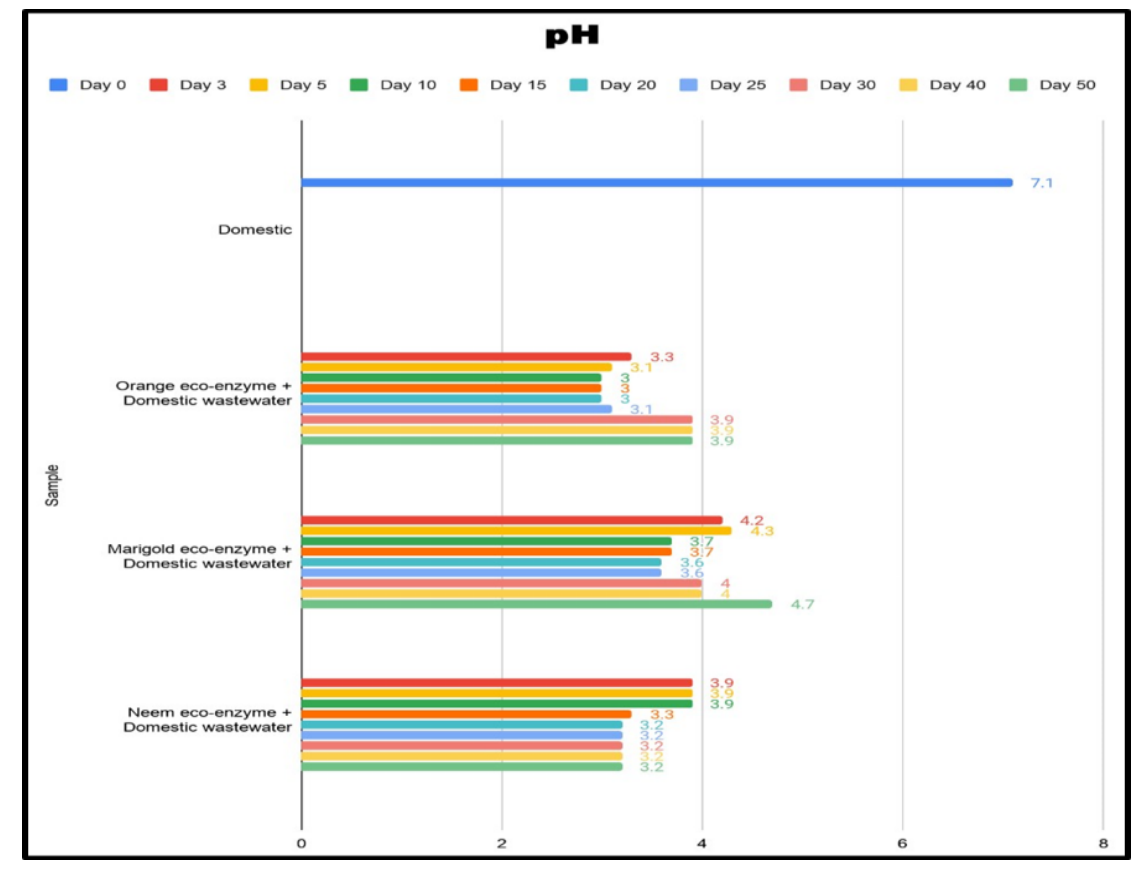

Figure 5 pH Graph

It was observed during the dilution period that the $\mathrm{pH}$ of domestic wastewater sample decreased from $7.1 \mathrm{before}$ mixing with eco-enzymes to 3.3, 4.2, and 3.9 after 3 days of addition of orange, marigold, and neem eco-enzymes respectively. The pH kept going down till 20 days for all samples and it stabilized at 3.2 from there on till the 50th day for the sample with neem eco-enzyme while it increased slightly to 3.9 and 4.7 for the samples with orange and marigold eco-enzymes respectively. The acidic nature of eco-enzyme solution influenced the domestic wastewater samples and made them acidic.

\subsubsection{TDS}

After treatment with eco-enzyme the variation was observed in TDS value of effluent and the corresponding variation in the characteristic of treated domestic wastewater samples is shown below (figure 6). 


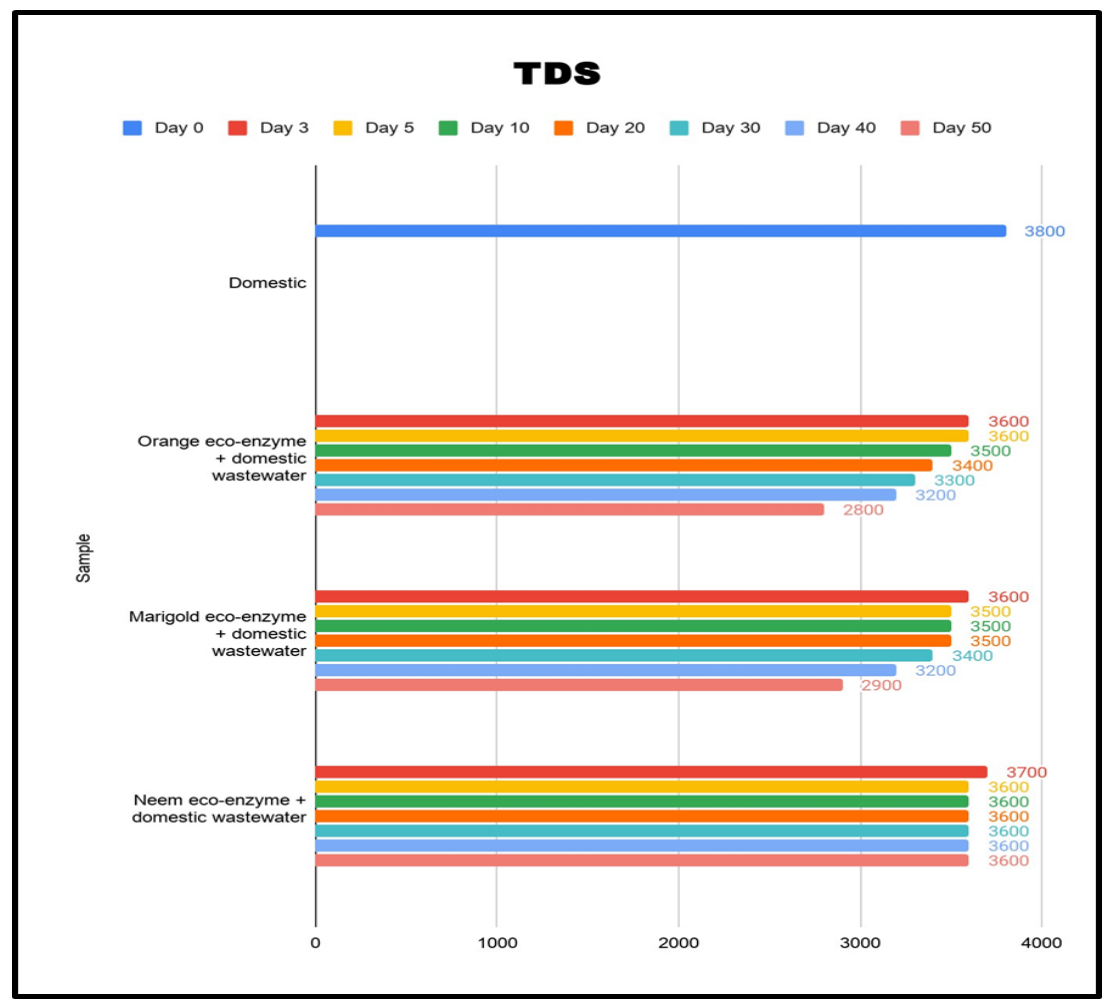

Figure 6 TDS Graph

TDS of the domestic wastewater sample was $3800 \mathrm{mg} / \mathrm{L}$ before being mixed with the eco-enzyme solutions. The TDS showed reduction in general for all the samples after being mixed with the eco-enzyme solutions gradually over the 50day dilution period. The sample with orange eco-enzyme showed the highest improvement as the value reduced to 2800 $\mathrm{mg} / \mathrm{L}$ from $3800 \mathrm{mg} / \mathrm{L}$ which is about $26.3 \%$ reduction. The sample with marigold eco-enzyme managed to reduce it to $2900 \mathrm{mg} / \mathrm{L}$ at the end of the 50-day dilution period. Whereas the sample with neem eco-enzyme managed to reduce it to $3600 \mathrm{mg} / \mathrm{L}$.

\subsection{3. $C O D$}

After treatment with eco-enzyme the variation was observed in COD value of effluent and the corresponding variation in the characteristic of treated domestic wastewater samples is shown below (figure 7).

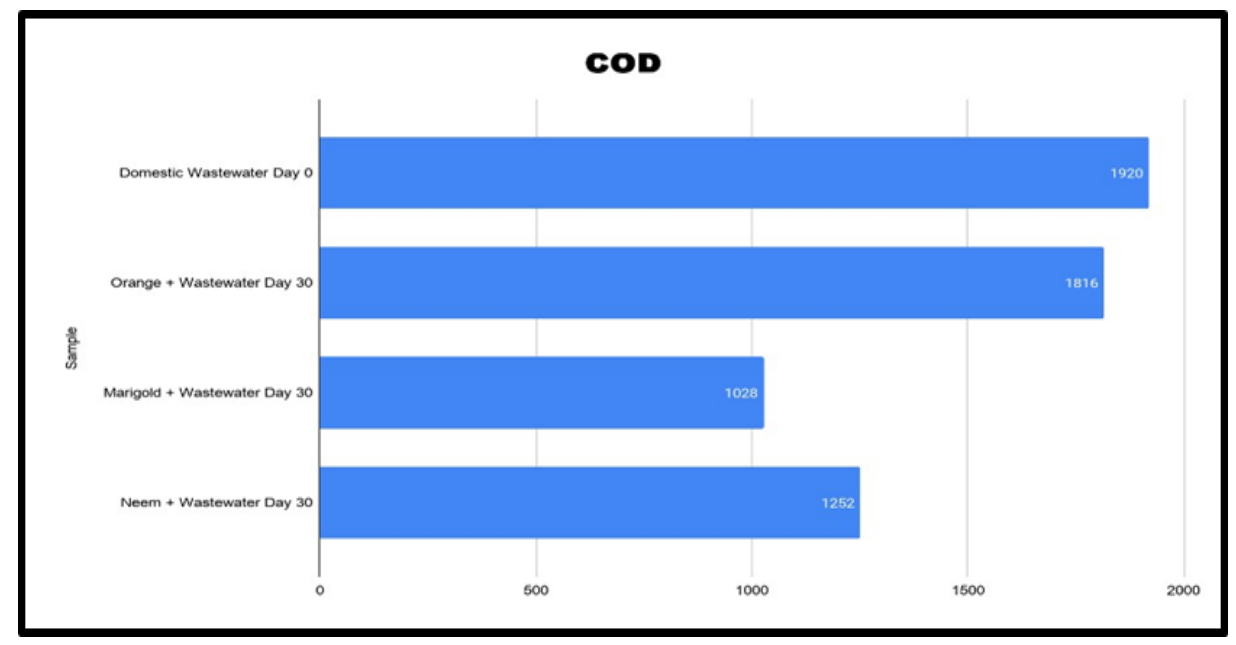

Figure 7 COD Graph 


\section{Discussion}

Water pollution is a major concern given the importance of water in survival and dependence on it for a variety of dayto-day activities. Increasing population and urbanisation is causing the quantity and rate of pollution to increase rapidly, thus putting a lot of strain on the demand of usable water, which is proving to be increasingly insufficient for all the uses. Not only that, water pollution causes a lot of harmful effects on the health of humans and environment. A lot of ecosystems are being destroyed and a lot of diseases are caused and spread because of it.

It has been pointed out that there is an urgent need to start identifying and applying many new methods to treat the wastewater before it mixes with the freshwater bodies. Moreover, the focus has to be on the viability of the method as it should be quick, cost effective, and efficient in treating the wastewater to meet various standards for different uses. Several studies have highlighted eco-enzyme as a probable solution to treat wastewater in an effective manner without causing harm to the environment.

In the present study, we explored the potential of eco-enzyme solutions made of orange (citrus) peels, marigold flowers, and neem leaves waste in treating a domestic wastewater sample. The domestic wastewater sample prepared had initial readings of $7.1 \mathrm{pH}, 3800 \mathrm{mg} / \mathrm{L}$ TDS, and $1920 \mathrm{mg} / \mathrm{L}$ COD indicative of a neutral-alkaline nature with high TDS and COD which make it unfit for drinking and agriculture amongst many other uses. The solutions prepared had initial readings of 3.1, 2.9, $3.2 \mathrm{pH}$ and 1300, 1400, $2500 \mathrm{mg} / \mathrm{L}$ TDS for orange, marigold, and neem eco-enzymes after 10 days of filtration indicating the acidic nature of the solutions.

The readings taken over the course of the dilution period of 50 days indicate reduction in the values of $\mathrm{pH}$, TDS, COD. The highest reduction in TDS was found in case of Orange eco-enzyme which had the lowest reading of $2800 \mathrm{mg} / \mathrm{L}$ after 50 days of dilution. The highest reduction in COD was found to be in the case of marigold eco-enzyme which had the reading of $1028 \mathrm{mg} / \mathrm{L}$ after 30 days of dilution. As far as $\mathrm{pH}$ is concerned, the closer it is to neutral the better and hence the $\mathrm{pH}$ readings of all 3 eco-enzyme solutions actually showed acidification of the sample for initial 20 days after which the $\mathrm{pH}$ started increasing towards 7. The marigold eco-enzyme had the best reading in this matter of 4.7 after 50 days of dilution period.

One of the studies had identified that $10 \%$ dilution of garbage and citrus enzymes is more efficient than $5 \%$ dilution when mixed with wastewater sample for treatment. Moreover, they noted that the longer time the eco-enzyme solution if kept for after filtration and before being mixed for treatment, the quicker it becomes in treating [24].

Present study shows that eco-enzyme has good potential to help reduce the TDS and COD values which indicate its effectiveness in purifying the domestic wastewater sample of its impurities to an extent. But the reduction in TDS and COD still wasn't enough to fall within permissible limits of $250 \mathrm{mg} / \mathrm{L}$ for COD and $2000 \mathrm{mg} / \mathrm{L}$ for TDS. We can also say that the domestic wastewater sample can still be improved in terms of its $\mathrm{pH}$ value with the help of some additional additives that do not affect the its quality and help to neutralise the $\mathrm{pH}$ value. More research about the effect of the ecoenzymes when kept for a longer time before being added with the domestic wastewater sample can potentially help understand the benefit in terms of shorter time taken to treat the wastewater.

\section{Conclusion}

The study highlights that solutions for domestic wastewater treatment which can be implemented at the household level on an interim basis need to be identified to help mitigate domestic water pollution till the time a solution can be found to treat huge quantities of water at once and effectively.

The eco-enzyme solution prepared using marigold flowers waste emerged ahead of the eco-enzyme solutions prepared using orange peels and neem leaves waste. It managed to reduce the COD of domestic wastewater sample from 1920 $\mathrm{mg} / \mathrm{L}$ to $1028 \mathrm{mg} / \mathrm{L}$ against $1252 \mathrm{mg} / \mathrm{L}$ for neem eco-enzyme and $1816 \mathrm{mg} / \mathrm{L}$ for orange eco-enzyme. It also managed to reduce TDS from $3800 \mathrm{mg} / \mathrm{L}$ to $2900 \mathrm{mg} / \mathrm{L}$ just behind orange eco-enzyme which reduced it to $2800 \mathrm{mg} / \mathrm{L}$, whereas neem eco-enzyme managed to reduce TDS to just $3600 \mathrm{mg} / \mathrm{L}$. And it also emerged ahead of the other two eco-enzymes in terms of managing to keep the $\mathrm{pH}$ closer to neutral as it ended up with a $\mathrm{pH}$ of 4.7 against that of 3.9 for orange ecoenzyme and 3.2 for neem eco-enzyme.

We can conclude that given the preparation of eco-enzyme solutions is in-expensive as they are prepared from the waste of fruits or flowers or leaves, which is abundant in quantity, they have great potential in not only treating domestic 
World Journal of Advanced Research and Reviews, 2021, 10(01), 323-333

wastewater, but also reducing the load on organic solid waste management. Moreover, eco-enzyme solutions thus prepared also have proven utility in cleaning, other domestic, and agricultural purposes.

\section{Compliance with ethical standards}

\section{Acknowledgments}

The author acknowledges Mr. Hardik Parekh and the authorities of Sophisticated Instrumentation Centre for Applied Research and Testing (SICART), Vallabh Vidyanagar, Anand (India) for providing their facilities and services for analysis and testing of useful parameters corresponding to the study.

\section{Disclosure of conflict of interest}

The authors declare no competing interests.

\section{References}

[1] Hossain MZ. Water: the most precious resource of our life. Global Journal of Advanced Research. 2015; 2(9): 1-1.

[2] Husain M, Husain Q. Applications of redox mediators in the treatment of organic pollutants by using oxidoreductive enzymes: a review. Critical Reviews in Environmental Science and Technology. 2007 Dec 5; 38(1): 1-42.

[3] Bani R. Wastewater Management. Waste Water: Evaluation and Management. 2011 Apr 1: 379.

[4] Shakunthala B, Shivanna S, Doddaiah S. Urban wastewater characteristic and its management in urban areas-a case study of Mysore City, Karnataka, India. Journal of Water Resource and Protection. 2010 Aug 26; 2010.

[5] Akpor OB, Otohinoyi DA, Olaolu DT, Aderiye BI. Pollutants in wastewater effluents: impacts and remediation processes. International Journal of Environmental Research and Earth Science. 2014; 3(3): 050-9.

[6] Rajasulochana P, Preethy V. Comparison on efficiency of various techniques in treatment of waste and sewage water-A comprehensive review. Resource-Efficient Technologies. 2016 Dec 1; 2(4): 175-84.

[7] Van der Hoek W. A framework for a global assessment of the extent of wastewater irrigation: the need for a common wastewater typology. Wastewater use in irrigated agriculture: Confronting the livelihood and environmental realities. 2004; 11-24.

[8] Penmatsa B, Sekhar DC, Diwakar BS, Nagalakshmi TV. Effect of Bio-Enzyme in the Treatment of Fresh Water Bodies. International Journal of Recent Technology and Engineering. 2019 June; 8(1S3): 308-310.

[9] Sato T, Qadir M, Yamamoto S, Endo T, Zahoor A. Global, regional, and country level need for data on wastewater generation, treatment, and use. Agricultural Water Management. 2013 Dec 1; 130: 1-3.

[10] Unuofin JO, Okoh AI, Nwodo UU. Aptitude of oxidative enzymes for treatment of wastewater pollutants: a laccase perspective. Molecules. 2019 Jan; 24(11): 20-64.

[11] Mugdha A, Usha M. Enzymatic treatment of wastewater containing dyestuffs using different delivery systems. Sci Rev Chem Commun. 2012; 2(1): 31-40.

[12] Das A, Mondal C. Studies on the utilization of fruit and vegetable waste for generation of biogas. Int. J. Eng. Sci. 2013 Sep 30; 3(9): 24-32.

[13] Nandan A, Yadav BP, Baksi S, Bose D. Recent scenario of solid waste management in India. World Scientific News. 2017(66): 56-74.

[14] Li X, Wang H, Gan S, Jiang D, Tian G, Zhang Z. Eco-stoichiometric alterations in paddy soil ecosystem driven by phosphorus application. PloS one. 2013 May 7; 8(5): e61141.

[15] Thirumurugan P, Mathivanan K. Production and analysis of enzyme bio-cleaners from fruit and vegetable wastes by using yeast and bacteria. Student project Report (DO Rc. No. 1082/2015A. 2016 Nov: 4-6.

[16] Dhavale V, Shimpi T, Koli V, Kamble R, Patil SB. Bio Enzymes From Organic Waste. International Journal of Emerging Technologies and Innovative Research. 2020 August; 7(8):196-200.

[17] Kumar A, Sadhya HK, Ahmad E, Dulawat S. Application of Bio-Enzyme in Wastewater (Greywater) Treatment. International Research Journal of Engineering and Technology. 2020 May; 7(5): 2886-2890. 
[18] Srimathi N, Subiksha M, Abarna J, Niranjana T. Biological treatment of Dairy Wastewater using Bio Enzyme from Citrus Fruit Peels. International Journal of Recent Technology and Engineering. 2020 May; 9(1): 292-295.

[19] Kurilla KK, Kumar P, Ramakrishna K. Treatment of Marigold flower effluent in Kaashyap Envergy Reactor. Research Journal of Life Sciences, Bioinformatics, Pharmaceutical and Chemical Sciences. 2018; 4(5): 464-475.

[20] Liu H, Wang Y, Liang C, Yang Q, Wang S, Wang B, Zhang F, Zhang L, Cheng H, Song S, Zhang L. Utilization of marigold (Tagetes erecta) flower fermentation wastewater as a fertilizer and its effect on microbial community structure in maize rhizosphere and non-rhizosphere soil. Biotechnology \& Biotechnological Equipment. 2020 Jan 1; 34(1): 522-31.

[21] Somani S, Ingole N, Patil S. Performance evaluation of natural herbs for antibacterial activity in water purification. International Journal of Engineering Science and Technology. 2011; 3(9): 7170-4.

[22] Pandey P, Khan F, Ahmad V, Singh A, Shamshad T, Mishra R. Combined efficacy of Azadirachta indica and Moringa oleifera leaves extract as a potential coagulant in ground water treatment. SN Applied Sciences. 2020 Jul; 2(7): 18.

[23] Janarthanan M, Mani K, Raja SR. Purification of Contaminated Water Using Eco Enzyme. InIOP Conference Series: Materials Science and Engineering 2020 Nov 1; 955(1): 012098.

[24] Nazim F, Meera V. Comparison of treatment of greywater using garbage and citrus enzymes. International Journal of Innovative Research in Science, Engineering and Technology. 2017; 6(4). 